\title{
STRUKTUR KOMUNITAS IKAN PADA EKOSISTEM LAMUN DI PANTAI PUDING KABUPATEN BANGKA SELATAN
}

Fish Communities Structure On Seagrass Ecosystems In Puding Beach Bangka Selatan.

\author{
Sania Prisilia ${ }^{1}$, Wahyu Adi $^{2}$, dan Arief Febrianto ${ }^{3}$ \\ ${ }^{1,2}$ Jurusan Manajemen Sumberdaya Perairan FPPB-UBB, Balunijuk \\ ${ }^{3}$ Badan Perencanaan Pembangunan Penelitian dan Pengembangan Daerah Kabupaten Bangka Selatan, Toboali \\ Email korespondensi: Sania_prisilia@yahoo.co.id
}

Diterima September; disetujui Oktober; tersedia secara online November

\begin{abstract}
Seagrass beds have a variety of roles in fish life, which can be used as nurseries, as a place for feeding ground, and for areas to seek protection. This study aims to analyze the structure of fish communities and seagrass communities and analyze the relationship of fish abundance with seagrass ecosystems. This research was conducted in March 2018 on the beach of Puding Air Banten II, Pasir Putih Village, Tukak Sadai District, Bangka Selatan Regency. Line transect method for seagrass data collection and fish data retrieval using fixed gill nets (gill net). The results of the study found that the total number of individual fish as much as 409 ind $/ \mathrm{m}^{2}$ consisted of 25 species. The highest abundance of fish found in Station I with Ambassis interrupta species as many as 241 ind $/ \mathrm{m}^{2}$. There were six types of seagrass found on the coast of Puding, namely Enhalus acoroides, Thalassia hemprichii, Halodule uninervis, Halophila spinulosa, Halophila decipiens and Cymodocea serrulata. The highest seagrass density was found at Station I with the seagrass Halodule uninervis species of 2541 ind $/ \mathrm{m}^{2}$. Correlation coefficient analysis shows that the abundance of fish with seagrass density has a significant value of 0.956 which is classified as having a very strong relationship. Fish have higher abundance with seagrass meadows which vegetate with mangroves..
\end{abstract}

Keywords: Fish, Seagrass, Fish Relationship with Seagrass

\section{PENDAHULUAN}

Keberadaan ekosistem lamun telah memberikan kontribusi yang cukup besar baik secara ekologis maupun ekonomis. Lamun secara ekologis berperan diantaranya sebagai stabilisator sedimen, filtrasi air, pendaur zat hara, dan pelindung erosi pantai, sedangkan secara ekonomis peran lamun yaitu sebagai penunjang sumber daya perikanan. Jenisjenis hewan laut hidup di padang lamun seperti mollusca, crustacea, ecinodermata, dugong, ikan dan lain-lainnya. Hasil penelitian yang telah dilakukan oleh Nagelkerken et al., (2000) melaporkan bahwa beberapa spesies ikan menggunakan daerah lamun dan mangrove sebagai daerah asuhan tempat membesarkan juvenile ikan (nursery ground). Kelimpahan dan kekayaan jenis tertinggi ditemukan di daerah padang lamun dan daerah berlumpur yang sekelilingnya ditumbuhi oleh vegetasi mangrove.

Bangka Selatan merupakan salah satu wilayah yang berada di Provinsi Kepulauan Bangka Belitung yang memiliki luas wilayah lebih kurang 3.607,08 $\mathrm{Km}^{2}$ atau $360.708 \mathrm{Ha}$ (BPS Bangka Selatan, 2017). Bangka Selatan memiliki kekayaan jenis hayati yang tinggi baik di daratan maupun perairan. Jenis hayati yang ada di Bangka Selatan salah satunya adalah lamun yang tersebar di beberapa daerah yaitu di pantai Tanjung Kerasak, pantai Tukak, pantai Tanjung Ruh, Pantai Penutuk dan Pantai Puding. Pantai Puding merupakan pantai yang terletak di Dusun Air Banten II Desa Pasir Putih, Kecamatan Tukak Sadai, Kabupaten Bangka Selatan.

Habitat lamun di pantai Puding ini berdekatan dengan mangrove dan memiliki area padang lamun yang unik dengan kondisi yang berbeda yaitu padang lamun yang dengan kerapatan yang tinggi dan rendah. Penelitian komunitas ikan padang lamun sebelumnya pernah dilakukan oleh Rappe (2010) yang menemukan adanya variasi nilai struktur komunitas ikan yang cukup besar pada padang lamun dengan kondisi yang berbeda. Kelimpahan ikan ditemukan lebih tinggi pada padang lamun dengan kerapatan yang tinggi baik itu tersusun oleh satu spesies lamun (monospesifik) maupun oleh lebih dari satu spesies lamun (multispesifik), dibandingkan pada padang lamun dengan kerapatan rendah dan pada daerah tidak bervegetasi. Pantai Puding juga dijadikan salah satu tempat mata pencaharian para nelayan di sekitar Dusun Air Banten II. Habitat padang lamun di pantai ini juga dekat dengan dermaga yang dijadikan sebagai tempat untuk pendaratan perahu nelayan sekitar. Kegiatan tersebut diduga dapat mengancaman ekosistem lamun yang dipengaruhi oleh kegiatan nelayan dalam menangkap ikan ataupun kepiting rajungan baik menggunakan perahu ataupun kapal. Gangguan lingkungan ini dapat mempengaruhi biota yang hidup di dalamnya khususnya ikan, baik dalam kelimpahan maupun keanekaragamannya. Lamun memiliki peranan yang penting bagi kehidupan ikan sehingga perlu dilakukannya penelitian tentang keterkaitan komunitas ikan yang berasosiasi dengan ekosistem lamun di pantai Puding.

\section{METODE PENELITIAN}

Penelitian ini dilaksanakan pada bulan Februari 2018 di pantai Puding Dusun Air Banten II Desa Pasir Putih Kecamatan Tukak Sadai Kabupaten Bangka Selatan. Peta lokasi penelitian tersaji pada Gambar 1. sebagai berikut : 


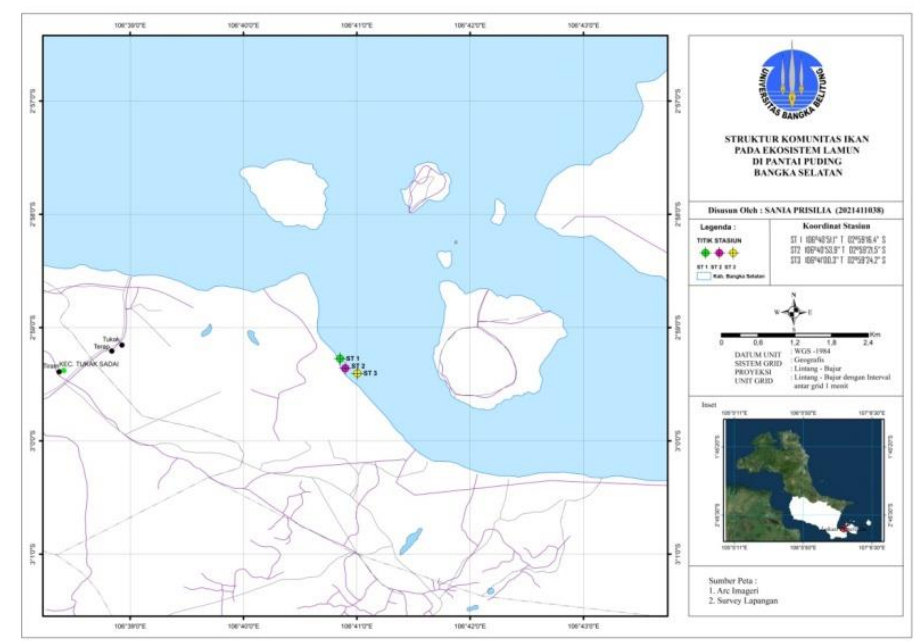

Gambar 1. Lokasi Penelitian

Alat dan bahan yang digunakan dalam penelitian ini dapat dilihat pada Tabel 1.

Tabel 1. Alat dan bahan penelitian

\begin{tabular}{lll}
\hline No. & Alat dan Bahan & Kegunaan \\
\hline 1 & Alat Tulis & Mencatat Hasil Penelitian Dilapangan \\
2 & GPS (Global Positioning system) & Menentukan Titik Koordinat Sampling \\
3 & pH Papper & Mengukur pH Pantai \\
4 & Gill net (jaring tetap) ukuran panjang & \\
& 25 m, lebar 1,3 m, ukuran mesh size 1 & Mengambil Sampel Ikan \\
& inch & \\
5 & Roll meter & Mengukur lamun \\
6 & Kamera & Dokumentasi penelitian \\
7 & Salinity hidrometer & Mengukur Salinitas \\
8 & Transek Kuadrat (1x1m) & pengamatan Lamun \\
9 & Plastik Sampel & Meletakkan Sampel Ikan ataupun Lamun \\
10 & Termometer & Mengukur Suhu \\
11 & Tongkat Skala & Mengukur Kedalaman \\
12 & Formalin & Mengawetkan Sampel Ikan ataupun Lamun \\
13 & DO meter & Mengukur oksigen terlarut \\
14 & Buku Identifikasi Lamun & Mengidentifikasi Lamun \\
15 & Buku Identifikasi Ikan & Mengidentifikasi Ikan \\
16 & Lamun & Sampel Penelitian \\
17 & Ikan & Sampel Penelitian \\
\hline
\end{tabular}

Penentuan titik sampling digunakan dengan menggunakan metode purposive sampling yaitu penentuan lokasi sampling dengan beberapa pertimbangan tertentu oleh peneliti (Fachrul, 2007). Stasiun pengambilan data yaitu sebanyak 3 stasiun dan setiap stasiun terbagi menjadi tiga sub stasiun yang dianggap mewakili kondisi pantai Puding.

Tabel 2. Pembagian stasiun pengambilan data

\begin{tabular}{|c|c|c|}
\hline Stasiun & Titik koordinat & Keterangan \\
\hline 1 & $\begin{array}{l}\mathrm{S}=02^{\circ} 59^{\prime} 16,4^{\prime \prime} \\
\mathrm{E}=106^{\circ} 40^{\prime} 51,1^{\prime \prime}\end{array}$ & $\begin{array}{l}\text { Terletak di sebelah kiri pantai yang berdekatan dengan } \\
\text { mangrove yang berbatasan dengan Sungai Banten }\end{array}$ \\
\hline 2 & $\begin{array}{l}\mathrm{S}=02^{\circ} 59^{\prime} 21,5^{\prime \prime} \\
\mathrm{E}=106^{\circ} 40^{\prime} 53,9^{\prime \prime}\end{array}$ & $\begin{array}{l}\text { Terletak di bagian tengah pantai yang berdekatan dengan } \\
\text { dermaga dan penambatan perahu nelayan }\end{array}$ \\
\hline 3 & $\begin{array}{l}S=02^{\circ} 59^{\prime} 24,2^{\prime \prime} \\
E=106^{\circ} 41^{\prime} 00,3^{\prime \prime}\end{array}$ & $\begin{array}{l}\text { Terletak di sebelah kanan pantai yang berdekatan dengan } \\
\text { mangrove dan Pulau Tinggi }\end{array}$ \\
\hline
\end{tabular}


Pengambilan ikan dilakukan dengan cara mengambil contoh ikan yang berada pada setiap sub stasiun. Pengambilan data ikan dilakukan dengan menggunakan jaring insang tetap (gill net) dengan mata jaring 1 inch, panjang jaring $25 \mathrm{~m}$, lebar 1,3 m untuk menangkap ikan di daerah padang lamun. Pengambilan sampel ikan dilakukan sebanyak 2 kali pengulangan yaitu pada saat air laut pasang bergerak surut dan surut bergerak pasang. Ikan diidentifikasi di Laboratorium Manajemen Sumberdaya Perairan Universitas Bangka Belitung dengan menggunakan buku identifikasi ikan berpedoman pada Reef Fish Identification Allen et al., (2003) dan FAO (1999).

Pengambilan sampel lamun menggunakan metode line transect quadrant dimana metode ini mengacu pada metode seagrass watch (McKenzie, 2002). Metode ini umum dipakai dalam pengamatan struktur komunitas padang lamun. Line transect quadrant dibentang tegak lurus terhadap garis pantai, yang dimulai dari titik 0 (nol) pada meteran. Penentuan titik 0 (nol) dimulai dari ditemukannya jenis lamun pertama, kemudian ditarik garis kearah laut sepanjang 50 m. Pengamatan lamun meliputi jenis lamun, tegakan lamun, peluang kehadiran lamun, dan persentase tutupan lamun.

Variabel ikan yang dianalisis adalah :

Komposisi jenis dapat diperoleh dari jumlah spesies ikan yang diperoleh dari stasiun penelitian yang ada (Setyobudiandi et al., 2009)

Kelimpahan relatif setiap jenis ikan dilakukan dengan perhitungan prosentase jumlah. Persamaan yang digunakan adalah dengan rumus :

Keterangan :

$$
(\mathrm{Kr})=\frac{n i}{N} \times 100 \%
$$

$\mathrm{Kr} \quad=$ komposisi jenis

$\mathrm{N} \quad=$ jumlah total individu

ni $\quad=$ jumlah individu dalam spesies

Indeks keanekaragaman digunakan untuk mengukur kelimpahan komunitas berdasarkan jumlah jenis spesies dan jumlah individu dari setiap spesies di suatu lokasi. Indeks keanekaragaman ikan digunakan indeks Shannon-Wiener (Setyobudiandy et al, 2009) :

Keterangan :

$$
\mathrm{H}^{\prime}=-\sum_{\mathrm{i}=1}^{\mathrm{s}} \mathrm{p} i \ln \mathrm{p} i
$$

H' = indeks keanekaragaman Shannon-Wiener

$\mathrm{Pi} \quad=$ perbandingan antara jumlah individu ikan ke-i dengan jumlah seluruh jenis ikan

Indeks Keseragaman digunakan untuk mengetahui seberapa besar kesamaan penyebaran jumlah individu setiap jenis, yaitu dengan membandingkan indeks keanekaragaman dengan nilai maksimumnya.Indeks keseragaman ditentukan berdasarkan rumus (Setyobudiandy et al, 2009) berikut :

$$
\text { Keterangan : } \quad \mathrm{E}=\frac{H^{\prime}}{\ln S}
$$

$\mathrm{E} \quad=$ indeks keseragaman

$\mathrm{H}^{\prime} \quad$ = indeks keanekaragaman

$\mathrm{S} \quad=$ jumlah total spesies

Indeks Dominansi Simpson digunakan untuk menggambarkan jenis yang paling banyak ditemukan dapat diketahui dengan menghitung nilai dominansinya dihitung dengan menggunakan rumus (Setyobudiandy et al, 2009) berikut :

Keterangan :

$$
\mathrm{C}=\sum\left(\frac{\mathrm{ni}}{\mathrm{N}}\right)^{2}
$$

C $\quad$ indeks dominansi

$\mathrm{n} i \quad=$ jumlah individu jenis ke-i

$\mathrm{N} \quad=$ jumlah total individu seluruh jenis

\section{HASIL DAN PEMBAHASAN}

\section{Struktur Komunitas}

Ikan yang tertangkap selama penelitian berjumlah 409 individu yang meliputi 25 spesies dari 18 famili. Berdasarkan jumlah jenis yang ditemukan, maka keanekaragaman jenis ikan di pantai Puding lebih tinggi bila dibandingkan dengan beberapa hasil penelitian yang dilakukan oleh Adi (2007) yang mendapatkan 15 spesies ikan pada pantai Pulau Panjang, Apriyanto (2014) mendapatkan 13 spesies ikan pada perairan Desa Berakit dan Rappe (2010) yang mendapatkan 21 jenis pada perairan Pulau Barang Lompo, Makassar. Kelimpahan ikan terbesar terdapat di Stasiun I sebesar $339 \mathrm{ind} / \mathrm{m}^{2}$ dengan 16 spesies, diikuti Stasiun III sebesar $40 \mathrm{ind} / \mathrm{m}^{2}$ dengan 10 spesies dan kelimpahan ikan terkecil yaitu terdapat di Stasiun II sebesar $30 \mathrm{ind} / \mathrm{m}^{2}$ dengan 12 spesies. Menurut Tebaiy et al., (2014) kriteria ikan dengan kategori individu tinggi yaitu berkisar 60 - 100 individu, kategori rendah berkisar 33-46 individu dan kategori rendah berkisar 1-30 individu. Kelimpahan ikan di stasiun penelitian ditampilkan pada Tabel 3 berikut : 
Tabel 3. Komposisi jenis ikan di setiap stasiun

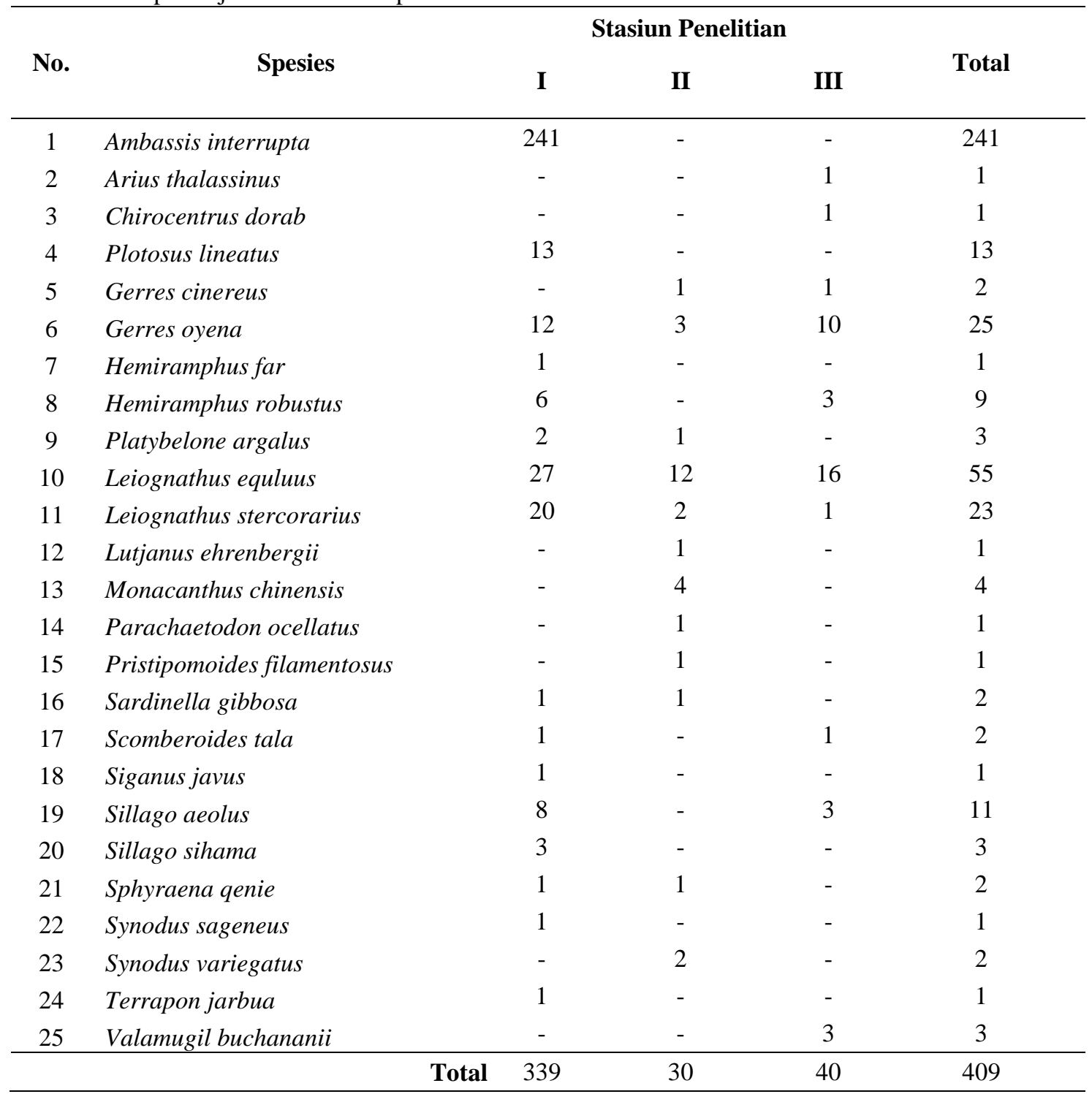

Sumber: (Hasil analisis, 2018).

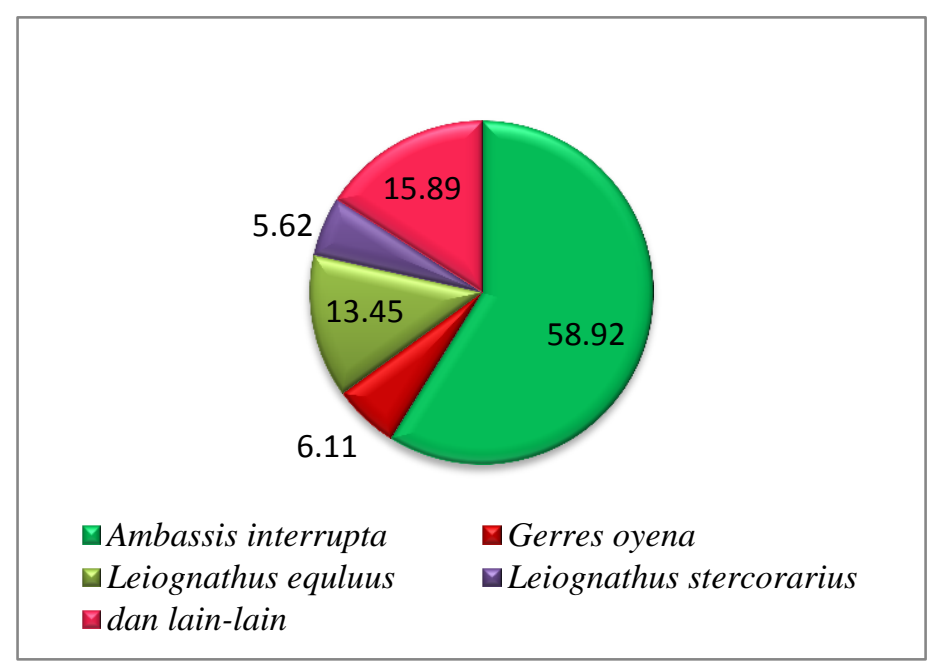


Kelimpahan relatif ikan dominan dengan 4 spesies tertinggi yaitu Ambassis interrupta sebesar nilai 58,92\%, Leiognathus equluus (13,45\%), Gerres Oyena (6,11\%) dan Leiognathus stercorarius (5,62\%). Kelimpahan relatif ikan lainnya yaitu Plotosus lineatus (3,18 \%), Gerres cinereus (0,49\%), Hemiramphus robustus (2,20\%), Monachantus chinensis (0,98\%), Platybelone argalus (0,73\%), Sardinella gibbosa (0,49\%), Scomberoides tala (0,49\%), Sillago aelous (2,69\%), Sillago sihama (0,73\%), Sphyraena qenie (0,49\%), Synodus variegatus (0,49\%), dan Valamugil buchananii $(0,73 \%)$. Kelimpahan relatif terendah ada beberapa spesies ikan yaitu Arius thalassinus, Chirocentrus dorab, Hemiramphus far, Lutjanus ehrenbergii, Pristipomoides filamentosus, Parachaetodon ocellatus, Siganus javus, Synodus sageneus dan Terrapon jarbua yaitu sebesar $0,24 \%$.

Hasil penelitian menunjukkan pada Stasiun I ikan dengan kelimpahan paling tinggi yaitu famili Ambassidae (Ambassis interrupta) dengan jumlah $241 \mathrm{ind} / \mathrm{m}^{2}$. Tingginya kelimpahan jenis ikan ini dikarenakan hasil tangkapan ikan di Stasiun I berdekatan dengan perairan estuaria dan terdapat hutan mangrove yang merupakan habitat ideal dari ikan tersebut. Nurfiarini et al., (2015) menyatakan bahwa jenis ikan Ambassis interrupta merupakan jenis ikan estuaria sejati. Ikan estuaria sejati merupakan spesies ikan yang daur hidupnya secara lengkap terjadi di perairan estuari. Kelimpahan ikan pada ekosistem padang lamun perairan pantai Puding turut dipengaruhi oleh kedekatannya dengan ekosistem mangrove.

Jenis ikan dengan kelimpahan terendah ditemukan di Stasiun II yaitu $30 \mathrm{ind} / \mathrm{m}^{2}$. Kelimpahan ikan berhubungan dengan karakteristik habitat, terutama persentase tutupan lamun, dimana persentase tutupan lamun pada Stasiun II rendah yaitu 13,444\%. Rahmawati (2012) yang menyatakan bahwa semakin rapat kondisi lamun maka tingkat perlindungan semakin tinggi dan kelimpahan ikan semakin besar. Famili-famili ikan karang ini ditemukan di pantai Puding khususnya pada Stasiun II dan Stasiun I. Fenomena ini mengindikasikan adanya terumbu karang di perairan pantai Puding. Humminga dan Duarte (2000) memperjelas bahwa perilaku berpindah ikan di komunitas yang berdekatan berkaitan dengan ketersediaan makanan dan proteksi dari lamun.

Kelimpahan ikan yang di temukan pada Stasiun III juga tergolong rendah yaitu $40 \mathrm{ind} / \mathrm{m}^{2}$. Beberapa jenis ikan yang ditemukan selama penelitian diantaranya dari famili ikan ekonomis penting seperti Carangidae, Lutjanidae, Mugilidae, dan Siganidae. Jenis ikan yang ditemukan tersebut menunjukan bahwa padang lamun berperan penting dalam menunjang usaha perikanan, karena menjadi daerah asuhan bagi ikan-ikan di sekitarnya. Triandiza (2013) menyatakan bahwa hasil tangkapan ikan yang berasosiasi dengan lamun terdapat beberapa spesies ikan ekonomis penting yaitu Carangidae, Lethrinidae, Lutjanidae, Mugilidae, Mulidae, Scaridae dan Siganidae.

Kelimpahan relatif tertinggi yaitu spesies Ambassis interrupta dengan nilai 58,92\%. Jenis ikan tersebut diindikasikan hidup bergerombol (schooling) dilihat dari hasil tangkapan yang di temukan selama penelitian berjumlah banyak dari spesies ikan lainnya serta habitat ideal dari jenis ikan tersebut adalah di perairan estuari yang turut dipengaruhi oleh kedekatannya dengan ekosistem mangrove. Tebaiy (2014) menyatakan bahwa ekosistem mangrove sebagai habitat ikan saling berkaitan dengan ruaya pasang, di mana pasang tertinggi mendukung kelimpahan ikan yang lebih besar dan saat surut akan terdistribusi pada ekosistem padang lamun. Kelimpahan relatif yang juga dominan lebih tinggi yaitu Gerres oyena, Leiognathus equluus dan Leiognathus strecorarius dimana ikan-ikan tersebut juga ditemukan dalam jumlah yang relatif lebih banyak dan ditemukan di setiap stasiun penelitian. Spesies-spesies ikan lain yang ditemukan dengan kelimpahan relatif lebih rendah disebabkan hanya di temukan di salah satu stasiun penelitian dengan jumlah sedikitnya yakni berkisar $1-11$ individu $/ \mathrm{m}^{2}$ sehingga mempengaruhi nilai kelimpahan relatif.

Indeks keanekaragaman menunjukkan bahwa Stasiun II memiliki nilai tertinggi yaitu sebesar 2,02, Stasiun III sebesar 1,757 sedangkan nilai keanekaragaman terendah yaitu terdapat pada Stasiun I sebesar 1,207. Tinggi rendahnya indeks keanekaragamn dapat ditentukan oleh beberapa faktor antara lain jumlah jenis yang tertangkap, kondisis ekosistem sebagai habitat suatu perairan dan adanya jenis yang melimpah dibanding lainnya. Berdasarkan kriteria indeks keanekaragaman menurut Setyobudiandi et al (2009), pantai Puding memiliki indeks keanekaragaman (H') tertinggi yaitu 2,02 dan dikategorikan dengan keanekaragaman sedang ( $\left.<\mathrm{H}^{\prime} \leq 3\right)$. Triandiza (2013) menyatakan bahwa makin besar nilai indeks keanekaragaman (H') menunjukkan komunitas semakin beragam. Kisaran nilai indeks keseragaman (E) antara 0,435 - 0,813 dan indeks dominansi (C) berkisar 0,204-0,519. Nilai indeks keseragaman menunjukkan kestabilan komunitas. Suatu komunitas dikatakan stabil apabila mempunyai nilai indeks keseragaman mendekati satu dan dikatakan tidak stabil bila indeks keseragamannya mendekati nol. Semakin kecil indeks keseragaman mengindikasikan penyebaran jenis tidak merata, beberapa jenis ditemukan lebih dominan dibandingkan yang lain. Sebaliknya, jika nilai indeks keseragaman lebih besar menggambarkan bahwa wilayah perairan tersebut jenis ikan tersebar secara relatif dan merata (Triandiza, 2013). Berdasarkan kategori diatas, maka pantai Puding dikatakan memiliki komunitas stabil, dengan indeks dominansi cenderung rendah. Triandiza (2013) menyatakan bahwa komunitas dikatakan stabil apabila nilai stabilitas (E mendekati 0,8 atau $\mathrm{H}^{\prime}>3$ ).

Tabel 4. Nilai indeks keanekaragaman (H'), keseragaman (E) dan Dominansi (C)

\begin{tabular}{lccc}
\hline & Stasiun I & Stasiun II & Stasiun III \\
\hline Keanekaragaman $\left(\mathrm{H}^{\prime}\right)$ & 1,207 & 2,02 & 1,757 \\
Keseragaman $(\mathrm{E})$ & 0,435 & 0,813 & 0,763
\end{tabular}


Sumber: (Hasil analisis, 2018)

Berdasarkan hasil penelitian ditemukan enam jenis lamun yang tersebar di 3 (tiga) stasiun penelitian yaitu Cymodocea serrulata, Thalassia hemprichii, Enhalus acoroides, Halodule uninervis, Halophila spinulosa dan Halophila decipiens. Jenis lamun yang tumbuh di pantai Puding termasuk ke dalam 12 (dua belas) jenis lamun yang ditemukan di seluruh perairan Indonesia yaitu Enhalus acoroides, Thalassia hemprichii, Thalassodendron ciliatum, Cymodocea rotundata, Cymodocea serrulata, Halodule uninervis, Halodule pinifolia, Halophila ovalis, Halophila minor, Halophila decipiens, dan Syringodium isoetifolium (Muhtadi et al., 2014).

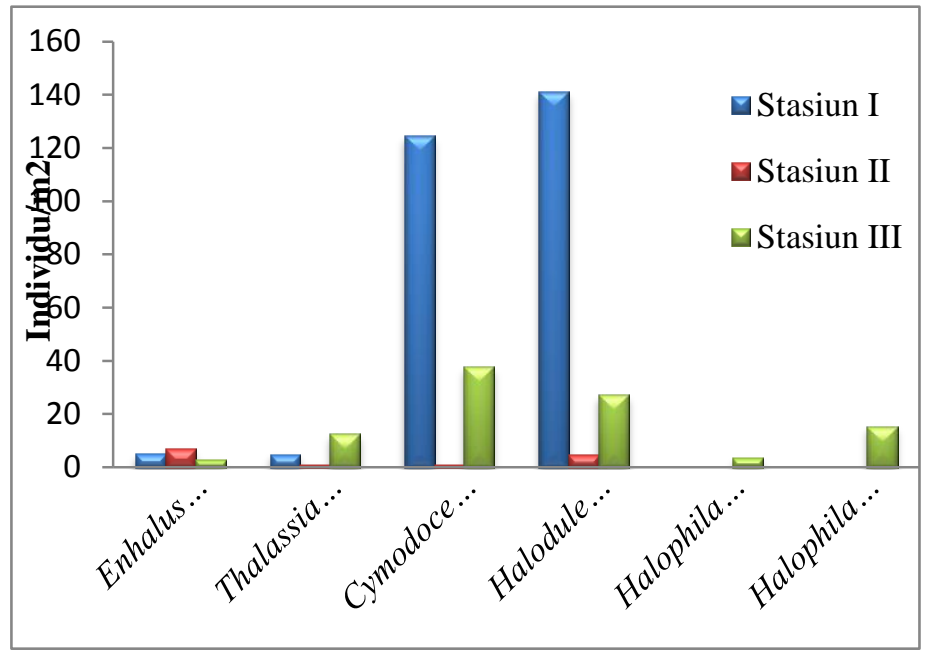

Gambar 3. Kerapatan jenis lamun di pantai Puding

Jenis lamun yang ditemukan pada penelitian ini memiliki kerapatan yang bervariasi, sebagaimana yang ditunjukkan oleh hasil analisis kerapatan di pantai Puding pada Gambar 3 hasil analisis data menunjukkan bahwa lamun yang memiliki kerapatan tertinggi ditemukan pada Stasiun I sebesar $276 \mathrm{ind} / \mathrm{m}^{2}$ yang menunjukkan bahwa pada Stasiun I kondisi lingkungannya masih dalam kondisi baik dan belum tercemar oleh aktivitas mayarakat atau nelayan karena lamun tumbuh dengan baik di lokasi tersebut, sedangkan kerapatan lamun terendah ditemukan di Stasiun II sebesar 14 $\mathrm{ind} / \mathrm{m}^{2}$ dimana pada Stasiun II terdapat dermaga. Nelayan setempat juga menjadikan pantai Puding sebagai lokasi penangkapan kepiting rajungan dengan menggunakan bubu lipat. Proses penangkapan kepiting juga dilakukan dengan menggunakan kapal, hal ini juga di duga menjadi pemicu adanya tekanan ekologis yang menjadikan kondisi perairan dan lingkungan khususnya di Stasiun II yang secara langsung berdekatan dengan dermaga yang dijadikan sebagai tempat pendaratan kapal nelayan menjadi sedikit terganggu sehingga mempengaruhi ekosistem lamun yang ada disana. Adli et al., (2016) menjelaskan bahwa kerapatan lamun yang berbeda yang disebabkan oleh adanya berbagai kegiatan manusia seperti adanya limbah/sampah, kegiatan nelayan setempat maupun untuk pariwisata. KepmenLH No. 200 Tahun 2004 juga menyatakan bahwa kerusakan padang lamun dapat disebabkan oleh semakin meningkatnya aktivitas manusia.

Hubungan kelimpahan ikan dengan kerapatan lamun menunjukkan hasil pada 3 (tiga) stasiun menunjukkan persamaan y =1,256x- 26,63. Hal ini mengindikasikan bahwa 91\% kelimpahan ikan dipengaruhi oleh kerapatan lamun.

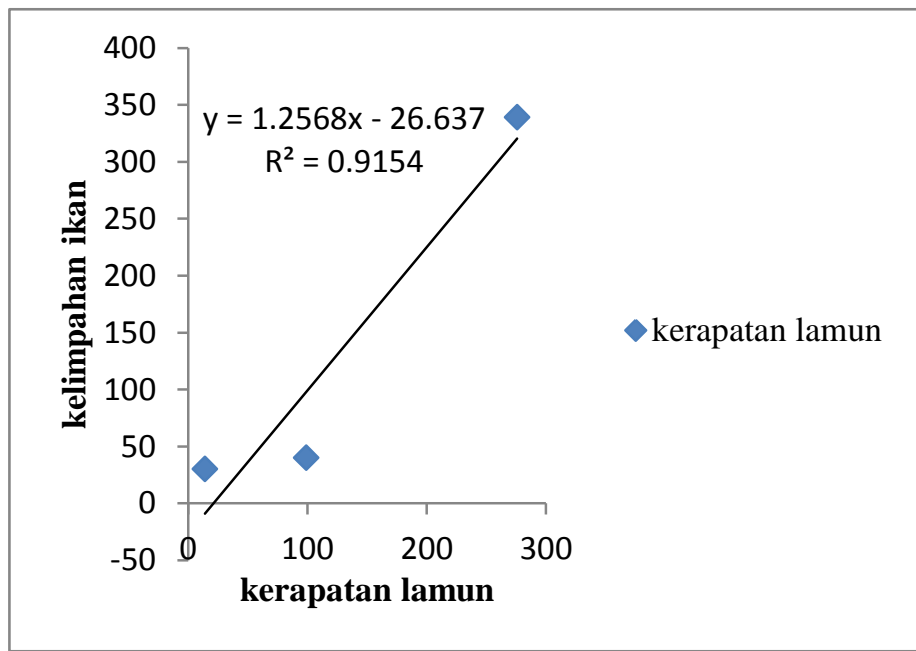

Gambar 4. Korelasi kelimpahan ikan dengan kerapatan lamun 
Tabel 5. Kriteria nilai korelasi

\begin{tabular}{cc}
\hline Interval Koefisien & Tingkat Hubungan \\
\hline $0,00-01,99$ & Sangat Lemah \\
$0,20-0,399$ & Lemah \\
$0,40-0,559$ & Cukup \\
$0,60-0,799$ & Kuat \\
$0,80-1,00$ & Sangat Kuat \\
\hline
\end{tabular}

Sumber: (Sugiyono, 2007).

Hasil analisis data menunjukkan bahwa nilai koefisien korelasi (r) antara kelimpahan ikan dengan kerapatan lamun signifikan yaitu sangat kuat (mendekati nilai 1) (Sugiyono, 2007). Hubungan kelimpahan ikan dengan kerapatan lamun di pantai Puding ini dibuktikan dari tingginya nilai kerapatan lamun dan tingginya nilai kelimpahan ikan. Kondisi ini juga membuktikan bahwa keberadaan ikan ditentukan oleh adanya lamun dengan kerapatan yang tinggi dibandingkan dengan kerapatan yang rendah. Padang lamun di pantai Puding juga membentuk vegetasi campuran yakni pada suatu stasiun penelitian ditemukan spesies lamun lebih dari satu spesies serta ekosistem pesisir yang ada di pantai Puding masih dalam kondisi baik dimana terdapat vegetasi mangrove yang berdekatan dengan daerah padang lamun. Humminga dan Duarte (2000) menyatakan bahwa kelimpahan dan keanekaragaman ikan lebih tinggi di daerah yang bervegetasi di bandingkan dengan yang tidak, karena daerah tersebut dapat menyediakan makanan dan perlindungan dari predator.

Kelimpahan ikan dengan kondisi lingkungan perairan yang dianalisis dengan menggunakan PCA (Principle Componen Analysis) memberikan informasi terhadap sumbu komponen utama yang terpusat pada dua sumbu utama F1 $(90,05 \%)$ dan F2 (6,55\%) dari keseluruhan persentase ragam total (lihat Gambar 5). Berdasarkan hasil analisis PCA memperlihatkan adanya 3 (tiga) pengelompokkan. Kelompok pertama terdiri dari Stasiun II dicirikan oleh parameter $\mathrm{pH}$, salinitas, dan suhu. Kelompok kedua terdiri dari Stasiun I yang dicirikan oleh parameter kecerahan, arus, dan TSS serta dicirikan oleh kelimpahan ikan dan kerapatan lamun. Kelompok ketiga terdiri dari Stasiun III yang dicirikan oleh parameter DO dan kedalaman.

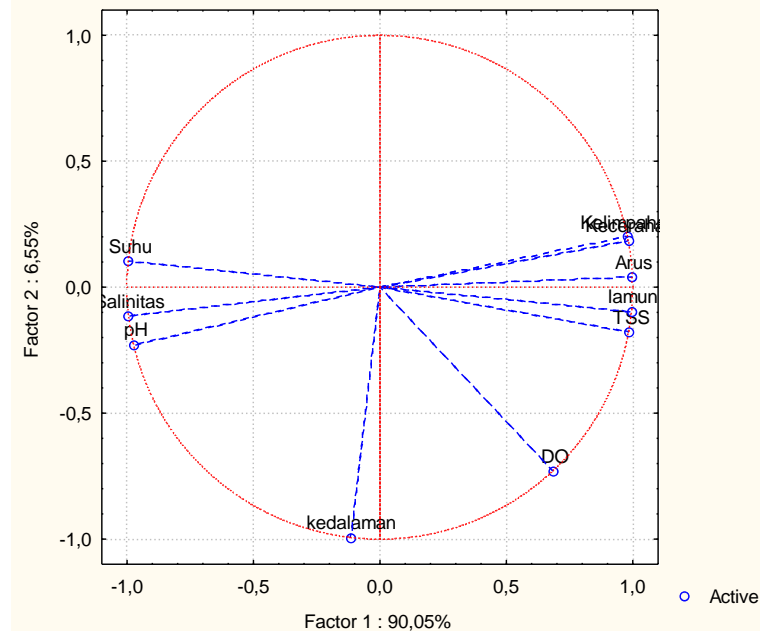

Gambar 5. Lingkaran korelasi antar variabel karakteristik habitat

Parameter fisik suatu perairan memegang peranan penting bagi kehidupan lamun dan biota laut lainnya. Keadaan parameter fisik perairan selama penelitian menunjukkan kriteria-kriteria yang ideal untuk pertumbuhan lamun di perairan dangkal. Berbagai jenis lamun pada perairan ini tergolong mampu hidup di kedalaman 1 meter. Nilai kedalaman perairan di pantai Puding di setiap stasiun masing-masing yaitu 0,98 m, 0,90 m dan 1,33 cm. Kedalaman tersebut mengindikasikan bahwa lamun bisa melakukan pertumbuhan dengan baik secara vegetasi tunggal maupun campuran. Kondisi ini berbeda dengan penelitian yang dilakukan oleh Adli et al., (2016) dimana kedalaman di bawah 1 meter merupakan kedalaman yang ideal untuk pertumbuhan vegetasi lamun.

Kecerahan yang diperoleh di masing-masing stasiun penelitian yaitu 0,78 meter, 0,31 meter dan 0,33 meter. KepmenLH No.51 Tahun 2004 menyatakan bahwa kecerahan untuk lamun yaitu >3 meter, kondisi ini mengindikasikan kecerahan di perairan pantai Puding dalam kondisi stabil untuk pertumbuhan lamun. Suhu yang di dapat dari hasil pengukuran tidak melebihi $30^{\circ} \mathrm{C}$. Kepmen LH No.51 Tahun 2004 menyatakan bahwa kisaran optimum suhu untuk 
lamun yaitu $28^{\circ} \mathrm{C}-30^{\circ} \mathrm{C}$. Suhu mempengaruhi proses-proses fisiologis lamun yaitu fotosintesis, laju respirasi, pertumbuhan dan reproduksi (Hoek et al., 2016). Arus laut sangat penting dalam kaitanya dengan kehidupan hewan atau organisme lain karena arus membantu transfer nutrien dan migrasi larva (Rosalina et al.,2018). Arus di pantai Puding yaitu berkisar $0,025 \mathrm{~m} / \mathrm{s}-0,03 \mathrm{~m} / \mathrm{s}$.

Lamun mentolerir suatu kisaran salinitas yang luas yaitu 6-60\%, bahkan dapat mentolerir air tawar dalam periode pendek (Adli et al., 2016). KepmenLH No.51 Tahun 2004 menyatakan baahwa kisaran salinitas untuk lamun yaitu 33-34\%o. Kisaran nilai salinitas yang diperoleh pada tiap stasiun masing-masing yaitu 27 ppt, 30 ppt dan 29 ppt. Kisaran salinitas tersebut merupakan kisaran yang menunjang laju pertumbuhan lamun. DO (Dissolved Oxygen) yang di dapat dari hasil pengukuran yaitu berkisar $6,7 \mathrm{mg} / \mathrm{l}-7,2 \mathrm{mg} / \mathrm{l}$ dimana kisaran DO tersebut merupakan kisaran optimum bagi suatu perairan. Kondisi ini diperjelas oleh KepmenLH No.51 Tahun 2004 yang menyatakan bahwa kisaran optimum bagi biota laut yaitu $>5 \mathrm{mg} / \mathrm{l}$. DO adalah kandungan oksigen yang terlarut dalam perairan yang merupakan suatu komponen utama bagi metabolisme organisme perairan yang digunakan untuk pertumbuhan, reproduksi, dan kesuburan lamun (Hoek et al., 2016).

pH air laut permukaan di Indonesia umumnya bervariasi antara 6-8,5 (Adli et al., 2016). Pada stasiun I, II dan III pengukuran $\mathrm{pH}$ didapatkan nilai berkisar antara 5,7 - 6. Kondisi ini menunjukkan tidak ada perbedaan yang signifikan $\mathrm{pH}$ antara stasiun I, II dan stasiun III, pada kisaran $\mathrm{pH}$ tersebut juga dapat disimpulkan bahwa stasiun I, II dan stasiun III di kategorikan dalam kurang produktif tingkat kesuburan perairannya. Kisaran $\mathrm{pH}$ yang baik untuk lamun ialah pada saat $\mathrm{pH}$ air laut 7,5 - 8,5, karena pada saat kondisi $\mathrm{pH}$ berada dikisaran tersebut dibutuhkan oleh lamun untuk fotosintesis (Hoek et al., 2016). pH pada perairan ini tergolong rendah hal ini dikarenakan pada saat pengulangan pengukuran kualitas perairan dalam kondisi hujan serta diindikasikan oleh adanya faktor sungai yang ada di sebelah perairan pantai Tukak yang berbatasan langsung dengan perairan pantai Puding dan diduga adanya pembusukan daun-daun lamun dan vegetasi mangrove yang hidup berdampingan dengan vegetasi lamun (Akhrianti, 2014). TSS (Total Suspended Solid) yang di dapat dari hasil pengukuran yaitu berkisar 474,7 mg/l - 507,3 mg/l dan melebihi baku mutu air laut untuk biota laut (KepmenLH No. 51 Tahun 2004) yaitu <5 NTU atau setara dengan $>1$ mg/l. Nilai TSS di pantai Puding juga tergolong tinggi dibandingkan dengan pengukuran TSS di pantai Tukak yang berdekatan dengan pantai Puding yaitu berkisar $18,34 \mathrm{mg} / \mathrm{l}-22,75 \mathrm{mg} / \mathrm{l}$ (Umroh et al., 2014).

Hasil analisis PCA (Principal Component Analysis) memberikan gambaran bahwa di lokasi penelitian diketahui beberapa parameter lingkungan perairan mempengaruhi kelimpahan ikan. Kelompok I terdiri dari Stasiun II yang dicirikan oleh parameter $\mathrm{pH}$, salinitas dan suhu sebagaimana yang terlihat pada Gambar 5 (a dan b) nilai ketiga parameter tersebut memiliki korelasi negatif dengan kelimpahan ikan yang membentuk F1-. Pada stasiun I, II dan III pengukuran $\mathrm{pH}$ didapatkan nilai berkisar antara 5,7-6. Latuconsina \& Rappe (2013) menyatakan bahwa kisaran $\mathrm{pH}$ yang optimal bagi pertumbuhan ikan yaitu 6,5 - 9,0. Kisaran $\mathrm{pH}$ menunjukkan bahwa pantai Puding tergolong optimal bagi pertumbuhan ikan namun tidak mempengaruhi tingginya kelimpahan ikan.

Kisaran nilai salinitas yang diperoleh pada tiap stasiun masing-masing yaitu 27 ppt, 30 ppt dan 29 ppt. Rosalina et al., (2018) menyatakan bahwa salinitas 27-29 ppt merupakan kisaran yang cocok untuk kehidupan lamun dan biota yang berasosiasi didalamnya. KepmenLH No. 51 Tahun 2004 menyatakan bahwa baku mutu salinitas air laut untuk biota laut berkisar 33-34 ppt. Kondisi ini mengindikasikan bahwa salinitas di pantai Puding tidak melebihi baku mutu namun dalam hal ini salinitas tidak memberikan pengaruh penting terhadap tingginya kelimpahan ikan. Hasil penelitian suhu di ketiga stasiun yang menunjukkan nilai suhu tidak melebihi $30^{\circ} \mathrm{C}$ yakni berkisar $29^{\circ} \mathrm{C}-30^{\circ} \mathrm{C}$. Suhu sangat menentukan kelimpahan ikan di suatu lokasi dikarenakan suhu berpengaruh terhadap proses rekrutmen. Hasil penelitian menunjukkan bahwa ikan sangat peka terhadap perubahan suhu. Suhu di lokasi penelitian mendukung kehidupan dan penyebaran organisme (Tebaiy et al., 2014) namun tidak memiliki pengaruh terhadap tingginya kelimpahan ikan. Rendahnya kelimpahan ikan pada Stasiun II juga diindikasikan oleh adanya pengaruh antropogenik yaitu tekanan ekologi seperti aktivitas nelayan yang ada di sekitar daerah tersebut.

Kelompok II terdiri dari Stasiun I yang dicirikan oleh parameter kecerahan, DO, arus, TSS serta kelimpahan ikan dan lamun itu sendiri yang saling berkorelasi positif membentuk F1+. Gambar 5 menunjukkan bahwa pada Stasiun I kelimpahan ikan dengan kecerahan memiliki nilai yang berbanding lurus. Hal ini diindikasikan bahwa tingginya kelimpahan ikan disebabkan oleh tingginya nilai kecerahan. Kecerahan suatu perairan yang baik menandakan bahwa optimalnya intensitas cahaya matahari yang menembus ke perairan. Hal ini akan sangat berpengaruh terhadap biota laut khususnya ikan. Ikan akan mudah melakukan pergerakan pada kondisi perairan yang cerah untuk mencari makan. Kecerahan mendukung proses penetrasi sinar matahari sampai ke kolom perairan sehingga proses fotosintesis dapat berlangsung (Tebaiy et al., 2014). Konsentrasi DO juga memiliki keterkaitan dengan kelimpahan ikan. Peranan DO cukup penting yakni untuk pernafasan dan juga merupakan salah satu komponen utama bagi metabolisme organisme perairan (Akhrianti, 2014).

Parameter arus juga memiliki nilai korelasi positif dengan tingginya kelimpahan ikan. Kecepatan arus di stasiun penelitian berkisar $0,025 \mathrm{~m} / \mathrm{s}-0,03 \mathrm{~m} / \mathrm{s}$ dimana pergerakan arus tergolong sangat lambat $(<0,1 \mathrm{~m} / \mathrm{s})$. Keadaan ini akan mempengaruhi ruaya ikan pada ketiga stasiun penelitian (Tebaiy et al., 2014). Rosalina et al., (2018) juga memperjelas bahwa arus laut sangat penting dalam kaitannya dengan kehidupan hewan atau organisme lain karena arus membantu transfer nutrien dan migrasi larva. Parameter TSS juga memiliki nilai korelasi positif dengan tingginya kelimpahan ikan. Keterkaitan parameter TSS dengan kelimpahan ikan di Stasiun I diindikasikan oleh keberadaan ikan jenis Ambassis interrupta dimana ikan ini memiliki nilai kelimpahan paling tinggi dibandingkan dengan spesies lain 
pada Stasiun I. Ikan ini memiliki kemampuan toleransi terhadap kekeruhan dikarenakan ikan jenis ini ideal hidup di daerah estuaria dan di daerah mangrove (Nurfiarini et al., 2015).

Kelompok III terdiri dari Stasiun III yang dicirikan oleh parameter kedalaman yang berkorelasi negatif dengan kelimpahan ikan dan membentuk F2-. Kedalaman pada Stasiun III memang lebih dalam dibanding dengan stasiun penelitian lainnya dan hal ini mengindikasikan bahwa semakin dalam suatu perairan maka akan membatasi kelimpahan ikan. Kondisi ini juga dikarenakan proses fotosintesis tidak dapat berlangsung secara maksimal sebab penetrasi cahaya yang masuk ke perairan semakin berkurang (Tebaiy et al., 2014).

\section{KESIMPULAN DAN SARAN Kesimpulan}

Struktur komunitas ikan di pantai Puding dikatakan memiliki komunitas stabil, dengan indeks dominansi cenderung rendah yakitu berkisar 0,204 - 0,519 dan memiliki indeks keseragaman sedang yaitu berkisar 0,435 - 0,813 menggambarkan bahwa jenis ikan tersebar secara relatif dan merata serta memiliki indeks keanekaragaman sedang yaitu berkisar 1,027 - 2,02. Struktur komunitas lamun di pantai Puding menunjukkan indeks keanekaragaman berkisar 0,847 - 1,491 yang tergolong rendah namun dikatakan memiliki komunitas yang stabil juga dengan indeks dominansi yang cenderung rendah yaitu berkisar 0,262 - 0,467 dan memiliki indeks keseragaman lamun yaitu berkisar 0,611 0,832 yang menggambarkan jenis lamun tersebar relatif merata. Analisis koefisien korelasi menunjukkan bahwa kelimpahan ikan dengan kerapatan lamun memiliki nilai yang siginifikan yaitu 0,956 yang tergolong mempunyai hubungan yang sangat kuat. Ikan memiliki kelimpahan lebih tinggi dengan padang lamun yang bervegetasi dengan mangrove. Analisis PCA (Priciple Component Analysis) menunjukkan bahwa tingginya kelimpahan ikan dipengaruhi oleh kerapatan lamun dan parameter kecerahan, DO yang berkisar 6,7 mg/l - 7,2 mg/l, arus berkisar 0,025 m/s - 0,03 $\mathrm{m} / \mathrm{s}$, serta TSS berkisar 474,7 mg/l - 507,3 mg/l, sedangkan rendahnya kelimpahan ikan berkaitan dengan parameter $\mathrm{pH}$ yang berkisar $5,7-6$, salinitas berkisar $27 \mathrm{ppt}-30 \mathrm{ppt}$, suhu berkisar $29^{\circ} \mathrm{C}-30^{\circ} \mathrm{C}$ serta kedalaman perairan yaitu berkisar 0,90 meter $-1,33$ meter.

\section{DAFTAR PUSTAKA}

Adi, Wahyu. 2007. Komposisi dan Kelimpahan Larva dan Juvenil Ikan yang Berasosiasi dengan Tingkat Kerapatan Lamun yang Berbeda di Pulau Panjang Jepara. AKUATIK-Jurnal Sumberdaya Perairan 1: 7-11

Adli, Andi, Achmad Rizal dan Zakirah Raihani Ya'la. 2016. Profil Ekosistem Lamun Sebagai Salah Satu Indikator Kesehatan Pesisir Perairan Sabang Tende Kabupaten Tolitoli. Jurnal Sains dan Teknologi Tadulako 5 : 49-62.

Allen, G., R. Steene, P. Humann, N. Deloach. 2003. Reef fish identification-Tropical Pacific. USA: New World Publication Inc. Florida

Aprianto, Sekti Hendro, Andi Zulfikar, dan Linda Waty Zen. 2014. Struktur Komunitas Ikan Di Ekosistem Padang Lamun Desa Berakit Kabupaten Bintan. Jurnal FIKP Universitas Maritim Raja Ali Haji. Kepulauan Riau.

Fachrul, M.F. 2007. Metode Sampling Bioekologi. Jakarta : Bumi Aksara.

FAO. 1999. FAO Species Identification Guide For Fishery Purpose. The Living Marine Resources Of The Western Central Pacific. Norflok, Virginia, USA: Departement Of Biological Sciences Old Dominion University. Volume 4 dan 5.

Humminga, MA, Duarte CM. 2000. Seagrass ecology. Inggris. 298 p: Cambridge University Press.

Keputusan Menteri Lingkungan Hidup No. 51 Tahun 2004. Tentang Baku Mutu Air Laut Untuk Biota.

McKenzie, L.J., dan Campbell, S.J. 2002. Manual for Community (citizen) Monitoring of Seagrass Habitat. Australia : Notherm Fisheries Centre CAIRNS.

Nagelkerken, I., G. Van der Velde, M. W. Gorissen, G. J. Meijer, T. van’t Hof \& C. den Hartog. 2000. Importance of Mangrove, Seagrass Beds anad the Shallow Coral Reef as a Nursery for Important Coral Reef Fishes, Using a Visual Census Technique. Est. Coast. Shelf Sci.,, 51: 31-44.

Nurfiarini, Amula. M. Mukhlis Kamal, Luky Adrianto, dan Setyo Budi Susilo. 2015. Keanekaragaman Hayati Sumberdaya Ikan Di Estuaria Segara Anakan, Cilacap Jawa Tengah. Jurnal BAWAL 7 : 25-34.

Rahmawati, S, Fahmi, dan Yusup, S.D., 2012, Komunitas Padang Lamun dan Ikan Pantai di Pantai Kendari Sulawesi Tenggara. Jurnal Ilmu Kelautan. 17 (4):190-198.

Rappe, Rohani Ambo. 2010. Struktur Komunitas Ikan Pada Padang Lamun Yang Berbeda Di Pulau Barrang Lompo. Jurnal Ilmu dan Teknologi Kelautan Tropis 2(2):62-73.

Setyobudiandi, I., Sulistiono., F. Yulianda., C.Kusmana,C.,S.Hariyadi.,A.Damar., A.Sembiring dan Bahtiar. 2009. Sampling dan Analisis Data Perikanan dan Kelautan; Terapan Metode Pengambilan Contoh di Wilayah Pesisir dan Laut. Bogor : Fakultas Perikanan dan Ilmu Kelautan IPB. 312 pp.

Sugiyono. 2007. Statistika untuk Penelitian. Bandung : CV Alfabeta.

Tebaiy, Selvi, Fredinan Yulianda, Achmad Fahrudin, dan Ismudi Muchsin. 2014. Struktur Komunitas Ikan Pada Habitat Lamun Di Teluk Youtefa Jayapura Papua. Jurnal Ikhtiologi Indonesia 14 (1):49-65

Triandiza, Teddy. 2011. Lembaga Penelitian Universitas Lampung. Seminar Nasional Sains \& Teknologi V. Lampung 19-20 November 2013. Lampung : Diversitas Ikan Pada Komunitas Padang Lamun Di Pesisir Perairan Pulau Kei Besar, Maluku Tenggara. hlm 666-677. 
